\title{
From proteins to genes: immunoanalysis in the diagnosis of muscular dystrophies
}

\author{
Rita Barresi ${ }^{1,2}$
}

\begin{abstract}
Muscular dystrophies are a large heterogeneous group of inherited diseases that cause progressive muscle weakness and permanent muscle damage. Very few muscular dystrophies show sufficient specific clinical features to allow a definite diagnosis. Because of the currently limited capacity to screen for numerous genes simultaneously, muscle biopsy is a time and cost-effective test for many of these disorders. Protein analysis interpreted in correlation with the clinical phenotype is a useful way of directing genetic testing in many types of muscular dystrophies. Immunohistochemistry and western blot are complementary techniques used to gather quantitative and qualitative information on the expression of proteins involved in this group of diseases. Immunoanalysis has a major diagnostic application mostly in recessive conditions where the absence of labelling for a particular protein is likely to indicate a defect in that gene. However, abnormalities in protein expression can vary from absence to very subtle reduction. It is good practice to test muscle biopsies with antibodies for several proteins simultaneously and to interpret the results in context. Indeed, there is a degree of direct or functional association between many of these proteins that is reflected by the presence of specific secondary abnormalities that are of value, especially when the diagnosis is not straightforward.
\end{abstract}

\section{Introduction}

The term muscular dystrophies (MDs) refers to a large group of genetically inherited disorders characterised by weakness and wasting of skeletal muscle. The subclassification is based on mode of inheritance, age of onset and distribution of muscles affected. Progress made in the past 25 years has enabled the discovery of new causative genetic defects with many novel proteins involved in MD (an updated list of MDs and responsible genes can be found at http://www.musclegenetable.org). Despite remarkable advances, this work is not yet complete, and although a large number of genes have been identified, a considerable number of patients still remain undiagnosed. Although a cure for most MDs is not yet available, an accurate diagnosis is key for natural history studies and to establish priorities for medical management, therapy and genetic counselling. Physical examination to determine the distribution of symptoms, together with medical and family history is central, but

Correspondence: rita.barresi@ncl.ac.uk

${ }^{1}$ NCG Diagnostic \& Advisory Service for Rare Neuromuscular Diseases, Muscle Immunoanalysis Unit, Dental Hospital, Richardson Road, Newcastle upon Tyne, UK

Full list of author information is available at the end of the article often the underlying genetic defect cannot be conclusively recognised on the basis of clinical information only. Indeed, differential diagnosis has to take into account the overlap of clinical features in different forms of MD and the heterogeneity in clinical presentation for many of the genes involved. Searching for gene mutations is the diagnostic gold standard but despite the rapidly evolving sequencing technologies, the analysis of multiple genes is still costly and time consuming and classification of gene mutations as pathogenic remains considerably challenging.

A wide range of laboratory tests aid in the diagnostic process. Serum level of creatine kinase (CK) is a sensitive parameter of muscle damage. The degree of CK elevation is variable in different $M D$ s and it can give an approximate indication of the type of disorder [1]. Electromyography enables differentiation between myopathic and neurogenic processes. Muscle magnetic resonance imaging, used to determine patterns of muscle involvement, represents a promising advance in facilitating differential diagnosis [2-4]. In this context, the analysis of the muscle biopsy plays a key role in the assessment of patients with MDs and provides useful diagnostic information to direct genetic analysis.
Ciomed Central

() 2011 Barresi; licensee BioMed Central Ltd. This is an Open Access article distributed under the terms of the Creative Commons Attribution License (http://creativecommons.org/licenses/by/2.0), which permits unrestricted use, distribution, and reproduction in any medium, provided the original work is properly cited. 


\section{Histopathology and immunoanalysis}

Although none of the types of MD can be distinguished on basic muscle histology, histopathology screening enables the identification of a number of features of significance when reviewed in context with clinical information. Many of the morphological abnormalities of muscle can be recognised in haematoxylin and eosin stained sections. Features such as fibre necrosis and regeneration, fibrosis and fatty infiltration, inflammation and vacuolated fibres seen in MDs are not specific to any particular type [5].

Diagnostic capabilities greatly improve when histological and histochemical tests are complemented with protein analysis. The development of antibodies (ABs) for many of the proteins affected in MDs has enabled the design of effective immunodiagnostic protocols to direct genetic screening. Identification of protein defects relies on immunohistochemical preparations and western blot analysis. Table 1 summarises the commercial ABs available for the analysis of MDs with both techniques. Tissue preparation and handling is key to the outcome of the immunoanalysis. To avoid ice crystal artefacts, skeletal muscle prepared for immunohistochemistry should be frozen in isopentane cooled in liquid nitrogen and stored at $-80^{\circ} \mathrm{C}$ or in liquid nitrogen. Provided that protein degradation is excluded, absence of labelling for one protein generally indicates a primary defect in the gene encoding for that protein, and reduced labelling may still be useful to suggest where to start the genetic analysis. In some cases (for example, dystrophinopathy) one protein may be abnormally expressed and others secondarily reduced. For this reason it is generally recommended to test each sample with several $A B s$ and to interpret the results by examining all proteins concurrently. Clinical data are essential not only to interpret the findings but also to select the appropriate $A B s$ for screening, which can vary according to the diagnosis suggested. However, testing with all of the available $\mathrm{ABs}$ is recommended as it may lead to the identification of primary protein defects in patients with unusual phenotypes $[6,7]$. Since biochemical analysis requires a significant portion of a muscle biopsy, multiplex western blot techniques have become popular in diagnostic laboratories to detect several proteins simultaneously [7]. Proteins separated by gel electrophoresis and labelled by immunoblot can be evaluated by size (molecular mass) and intensity (abundance) compared to a control. A loading control such as myosin heavy chain should be used to indicate how much 'muscle' protein is loaded in each sample and to establish an adequate baseline for protein quantification, since dystrophic muscle samples may be fibrotic or contain fat. Importantly, biopsy of end stage muscle is unlikely to provide diagnostic
Table 1 Commercial antibodies for the diagnosis of muscular dystrophies

\begin{tabular}{|c|c|c|c|c|}
\hline Antigen & Host/lsotype & Clone & IHC & WB \\
\hline Spectrin & Mouse lgG2b & $\mathrm{RBC2/3D5}$ & Y & $\mathrm{N}$ \\
\hline Dystrophin (N term) & Mouse lgG2a & Dy $10 / 12 B 2$ & Y & Y \\
\hline Dystrophin (rod domain) & Mouse lgG2a & Dy4/6D3Y & Y & Y \\
\hline Dystrophin (C-term) & Mouse lgG1 & Dy8/6C5 & Y & Y \\
\hline Dystrophin (C-term) & Mouse $\operatorname{lgG} 1$ & MANDRA1 & Y & Y \\
\hline Utrophin & Mouse $\operatorname{lgG} 1$ & DRP3/20C5 & Y & N \\
\hline nNOS & Mouse lgG1 & RN5 & Y & N \\
\hline Myotilin & Mouse $\operatorname{lgG1}$ & RS034 & Y & N \\
\hline Lamin A/C & Mouse $\lg G 2 b$ & 636 & $Y^{*}$ & N \\
\hline Caveolin-3 & Mouse $\operatorname{lgG} 1$ & 26/Caveolin 3 & Y & Y \\
\hline Calpain-3 & Mouse $\lg G 2 \mathrm{~b}$ & Calp3d/2C4 & N & Y \\
\hline Calpain-3 & Mouse IgG2a & Calp3d/12A2 & $\mathrm{N}$ & Y \\
\hline Dysferlin & Mouse $\operatorname{lgG1}$ & Ham1/7B6 & Y & Y \\
\hline Dysferlin & Mouse $\lg G 2 \mathrm{~b} \kappa$ & Ham3/17B2 & Y & N \\
\hline$\alpha$-Sarcoglycan & Mouse IgG1 & $\mathrm{Ad} 1 / 20 \mathrm{A6}$ & Y & Y \\
\hline$\beta$-Sarcoglycan & Mouse lgG1 & b-sarc/5B1 & Y & $\mathrm{N}$ \\
\hline$\gamma$-Sarcoglycan & Mouse $\operatorname{lgG} 2 \mathrm{~b} \kappa$ & $35 \mathrm{DAG} / 21 \mathrm{~B} 5$ & Y & Y \\
\hline$\delta$-Sarcoglycan & Mouse $\operatorname{lgG} 2 \mathrm{a} \kappa$ & $d-\operatorname{sarc} 3 / 12 C 1$ & Y & $\mathrm{N}$ \\
\hline Telethonin & Mouse lgG1 & G-11 & $\mathrm{N}$ & $\mathrm{N}$ \\
\hline$\alpha$-Dystroglycan & Mouse IgM & $11 \mathrm{H} 6$ & Y & Y \\
\hline$\alpha$-Dystroglycan & Mouse IgG1 & VIA4-1 & Y & Y \\
\hline$\beta$-Dystroglycan & Mouse IgG2a & 43DAG1/8D5 & Y & Y \\
\hline Laminin $\alpha 2$ 80kDa & Mouse IgG1 & $5 \mathrm{H} 2$ & Y & Y \\
\hline Laminin $\alpha 2300 \mathrm{kDa}$ & Mouse $\lg G 1 \kappa$ & Mer3/22B2 & Y & $\mathrm{N}$ \\
\hline Laminin a2 300kDa & Rat $\lg \mathrm{G} 1$ & $4 \mathrm{H} 8$ & Y & $\mathrm{N}$ \\
\hline Laminin $\alpha 5$ & Mouse IgG2a & $4 C 7$ & Y & $\mathrm{N}$ \\
\hline Laminin $\beta 1$ & Mouse $\lg G 1 \kappa$ & $4 \mathrm{E} 10$ & $Y^{*}$ & N \\
\hline Laminin $\gamma 1$ & Mouse $\lg \mathrm{G} 1 \kappa$ & $2 \mathrm{E} 8$ & Y & $\mathrm{N}$ \\
\hline Laminin $\gamma 1$ & Mouse lgG2a & A5 & Y & N \\
\hline Collagen VI & Mouse lgG1 & $3 C 4$ & Y & $\mathrm{N}$ \\
\hline Collagen VI & Rat $\lg G 1 \kappa$ & VI-26 & Y & $\mathrm{N}$ \\
\hline Perlecan & Mouse $\lg \mathrm{G} 2 \mathrm{a} \kappa$ & A7L6 & Y & $\mathrm{N}$ \\
\hline Emerin & Mouse lgG1 & $4 \mathrm{G} 5$ & Y & N \\
\hline Desmin & Mouse $\operatorname{lgG1}$ & D33 & Y & $\mathrm{N}$ \\
\hline$\alpha B-C r y s t a l l i n$ & Rabbit Polyclonal & G2JF & Y & $\mathrm{N}$ \\
\hline VCP & Mouse lgG1 & $18 / N C P$ & Y & $\mathrm{N}$ \\
\hline PTRF-cavin & Mouse lgG1 & 4/PTRF & $\mathrm{N}$ & Y \\
\hline MHC class I & Mouse $\lg G 2 \mathrm{a}$ & W6-32 & Y & N \\
\hline Neonatal Myosin & Mouse $\operatorname{lgG1}$ & WB-MHCn & Y & $\mathrm{N}$ \\
\hline
\end{tabular}

The list includes antibodies for the detection of primary or secondary defects and for the assessment of quality and preservation of samples.

*Immunoanalysis possible but not informative for diagnostic assessment.

$\mathrm{IHC}=$ immunohistochemistry; $\mathrm{MHC}=$ major histocompatibility complex; $\mathrm{N}=$ labelling not carried out routinely or antibody not tested/not suitable for test; nNOS =

neuronal nitric oxide synthase; PTRF = polymerase I and transcript release factor; VCP $=$ valosin-containing protein; $\mathrm{WB}=$ western blot; $\mathrm{Y}=$ labelling carried out routinely.

information due to loss of myofibres and predominance of fibrovascular and adipose tissue. However a symptomatic muscle should be selected to appreciate distinctive pathologic features. Ultrasound or MRI techniques may aid the selection of the biopsy site $[4,8]$. 
The use of controls is crucial to assess the quality and preservation of samples as well as to discriminate pathological from natural changes (Table 2). In immunohistochemistry, the $A B$ to $\beta$-spectrin serves as a marker of sarcolemmal integrity and it is used to evaluate the expression of plasma membrane proteins. In fact, necrotic fibres or fibres within degraded biopsies generally lack sarcolemmal labelling and could give false negative results. Similarly, ABs for laminin $\gamma 1$ and perlecan can be used to check the integrity of the basal lamina if a reduction in laminin $\alpha 2$ or collagen VI is detected. By contrast, laminin $\beta 1$ chain is not suitable for this purpose as it is often secondarily reduced in both recessive and dominant conditions [9]. Importantly, the expression of some proteins is developmentally regulated. For instance, $\beta$-spectrin and neuronal nitric oxide synthase (nNOS) are weakly expressed in regenerating fibres, which instead label for markers such as utrophin, desmin and major histocompatibility complex (MHC) class I [10] (Figure 1 and data not shown). Laminin $\alpha 5$ is also present in regenerating fibres but its expression may also be increased in dystrophinopathies and inflammatory myopathies (Figure 1). To facilitate the interpretation of these findings serial sections should also be labelled for neonatal myosin heavy chain (Neo-MHC), as a marker of regenerating fibres, but caution is needed since Neo-MHC is also found in fibres with arrested development (Figure 1) and atrophic fibres and reappears after denervation [5,11]. Other isoforms of $\mathrm{MHC}$, such as embryonic MHC, are expressed more transiently in earlier stages and can be detected mainly in the smaller regenerating fibres [10].

\section{Investigation of specific disorders}

Protein analysis is effective in guiding genetic analysis in many, but not all, types of MDs (Table 3). Its major diagnostic application is in recessive conditions where the protein defect can vary from absence to partial reduction. In most dominant diseases the results may be inconclusive, as both normal and abnormal alleles produce protein. Also, genetic analysis is very reliable in conditions such as myotonic dystrophy and facioscapulohumeral muscular dystrophy (FHSD) and a diagnosis can be achieved without the need of a muscle biopsy. Details of clinical features of MDs and other diagnostic techniques are not discussed in the present review. Here we focus on the pattern of protein expression and specific secondary changes in those types of MDs where the analysis of muscle biopsy with commercially available ABs plays a major role in facilitating the diagnosis.

Genes affected in MDs encode for diverse proteins with various distribution and function within the muscle cell. Direct or functional association between many of these proteins is reflected by the presence of specific secondary abnormalities that are of diagnostic value. In particular, the expression of proteins of the dystrophin glycoprotein complex (DGC) appear to be strictly interrelated, therefore forms of MDs that affect this group of proteins are discussed together in this review.

Table 2 Protein controls for immunohistochemistry

\begin{tabular}{|c|c|c|c|c|}
\hline Control purpose & Protein & Normal expression & Secondary changes & Notes \\
\hline $\begin{array}{l}\text { Preservation of } \\
\text { plasma membrane }\end{array}$ & Spectrin & Sarcolemma & $\begin{array}{l}\text { Reduction in immature/regenerating fibres. } \\
\text { Absent or patchy in necrotic fibres. } \\
\text { Absent of patchy in biopsies with artefacts. }\end{array}$ & $\begin{array}{l}\text { May be reduced in fibres with Neo-MHC, } \\
\text { utrophin, laminin } \alpha 5, \mathrm{MHC} \text { class I. } \\
\text { Absence of other sarcolemmal proteins. }\end{array}$ \\
\hline $\begin{array}{l}\text { Regenerating } \\
\text { fibres }\end{array}$ & Neo-MHC & Fibres unlabelled & $\begin{array}{l}\text { Labelling of regenerating fibres. } \\
\text { Labelling of atrophic fibres. }\end{array}$ & $\begin{array}{l}\text { Coexpressed with laminin } \alpha 5, \mathrm{MHC} \text { class } \\
\text { l, utrophin }\end{array}$ \\
\hline $\begin{array}{l}\text { Regenerating } \\
\text { fibres }\end{array}$ & Utrophin & $\begin{array}{l}\text { Vessels, nerves and } \\
\text { neuromuscular junction }\end{array}$ & $\begin{array}{l}\text { Labelling of regenerating fibres. } \\
\text { Labelling of mature fibres in DMD/BMD. }\end{array}$ & $\begin{array}{l}\text { Coexpressed with Neo-MHC, laminin } \alpha 5 \text {, } \\
\text { MHC class I }\end{array}$ \\
\hline $\begin{array}{l}\text { Regenerating } \\
\text { fibres, denervation }\end{array}$ & $\mathrm{nNOS}$ & Sarcolemma & $\begin{array}{l}\text { Reduction in regenerating and denervated } \\
\text { fibres. } \\
\text { Absent in DMD, some BMD and } \\
\text { sarcoglycanopathies. }\end{array}$ & $\begin{array}{l}\text { Reduced in fibres expressing utrophin, } \\
\text { Neo-MHC, laminin } \alpha 5, \mathrm{MHC} \text { class I }\end{array}$ \\
\hline $\begin{array}{l}\text { Regenerating } \\
\text { fibres }\end{array}$ & $\begin{array}{l}\text { Laminin } \\
\alpha 5\end{array}$ & Blood vessels & $\begin{array}{l}\text { Labelling of regenerating fibres. Labelling of } \\
\text { mature fibres in MDC1A. }\end{array}$ & $\begin{array}{l}\text { Coexpressed with utrophin, Neo-MHC, } \\
\text { laminin } \alpha 5, \mathrm{MHC} \text { class I }\end{array}$ \\
\hline $\begin{array}{l}\text { Inflammation, } \\
\text { regenerating fibres }\end{array}$ & MHC class & Blood vessels & $\begin{array}{l}\text { Labelling of regenerating fibres. } \\
\text { Sarcolemmal labelling in diseases with } \\
\text { inflammatory component. }\end{array}$ & $\begin{array}{l}\text { Coexpressed with utrophin, Neo-MHC, } \\
\text { laminin } \alpha 5\end{array}$ \\
\hline $\begin{array}{l}\text { Basement } \\
\text { membrane, } \\
\text { integrity }\end{array}$ & Laminin $\beta 1$ & $\begin{array}{l}\text { Sarcolemma and blood } \\
\text { vessels }\end{array}$ & $\begin{array}{l}\text { Sarcolemmal labelling reduced or patchy in } \\
\text { many dominant and recessive conditions }\end{array}$ & \\
\hline $\begin{array}{l}\text { Basement } \\
\text { membrane, } \\
\text { integrity }\end{array}$ & $\begin{array}{l}\text { Laminin } \\
\gamma 1 \\
\text { Perlecan }\end{array}$ & $\begin{array}{l}\text { Sarcolemma and blood } \\
\text { vessels }\end{array}$ & Patchy in biopsies with artefacts & \\
\hline
\end{tabular}




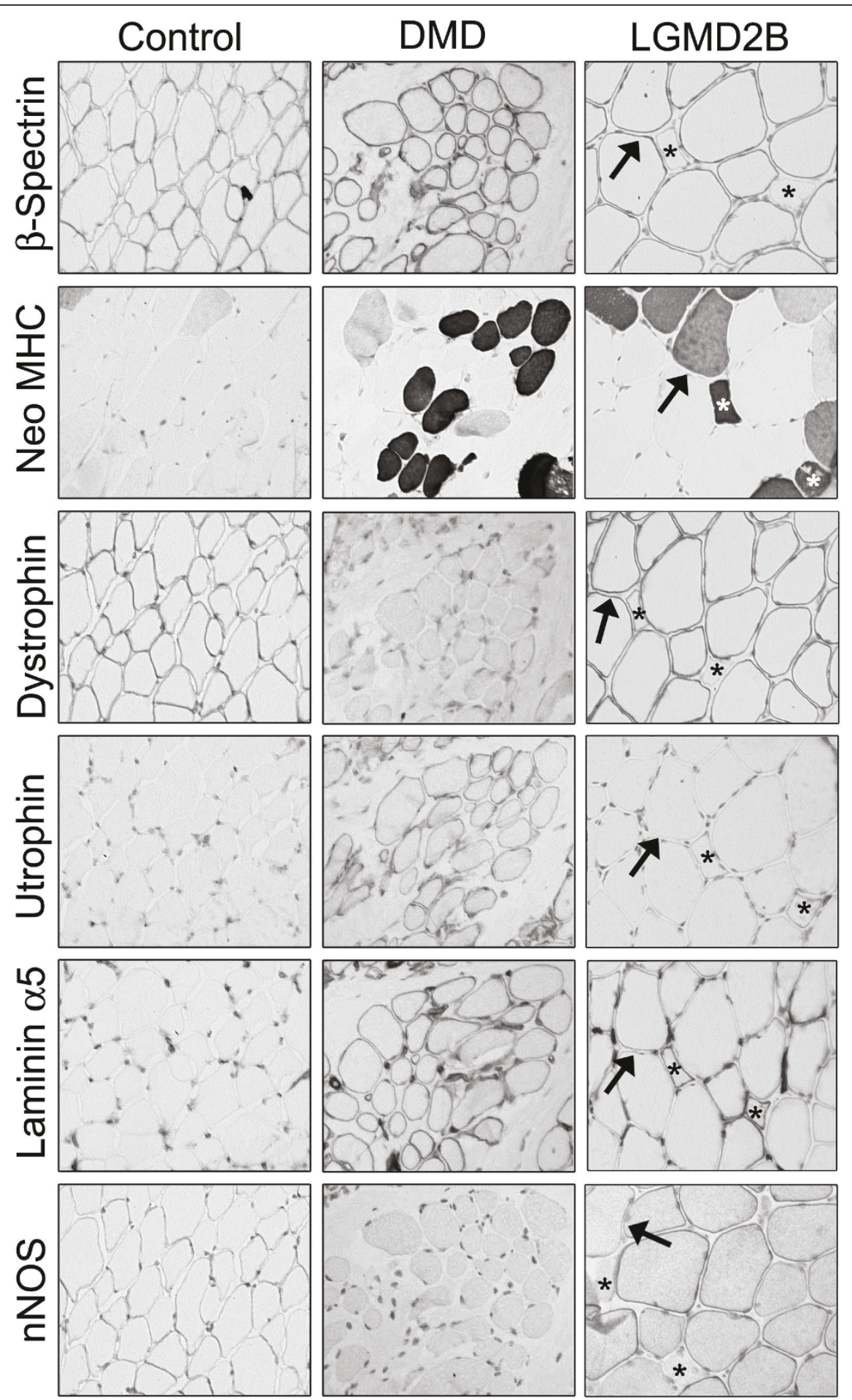

Figure 1 Control tests for necrosis and regeneration. Expression of various markers of sarcolemmal integrity ( $\beta$-spectrin) and regeneration (neonatal myosin heavy chain (Neo-MHC), utrophin and laminin $\alpha 5$ ) in serial sections of control, Duchenne muscular dystrophy (DMD) and limb girdle muscular dystrophy (LGMD)2B muscle. Arrows indicate abnormal immature fibres positive for Neo-MHC; stars highlight regenerating fibres at different stages. The pattern of expression of the regeneration markers is less defined in DMD muscle due to the overall upregulation of utrophin and laminin $\alpha 5$ and secondary loss of neuronal nitric oxide synthase (nNOS). 
Table 3 Primary and secondary protein abnormalities in muscular dystrophies

\begin{tabular}{|c|c|c|c|}
\hline Disease & Gene(s) & Primary protein defect & Secondary changes \\
\hline DMD & $D M D$ & Dystrophin absent or very reduced with all antibodies & $\begin{array}{l}\text { Utrophin overall upregulated } \\
\text { Sarcoglycans reduced/absent } \\
\text { Dystroglycan reduced/absent nNOS } \\
\text { absent }\end{array}$ \\
\hline BMD & DMD & $\begin{array}{l}\text { Dystrophin reduced in size or amount or absent with at } \\
\text { least one antibody }\end{array}$ & $\begin{array}{l}\text { Utrophin overall upregulated } \\
\text { Sarcoglycans reduced/absent } \\
\text { Dystroglycan reduced/absent } \\
\text { nNOS may be absent }\end{array}$ \\
\hline DMD/BMD carriers & $D M D$ & $\begin{array}{l}\text { Dystrophin patchy, mosaic pattern with at least one } \\
\text { antibody }\end{array}$ & $\begin{array}{l}\text { In fibres without dystrophin } \\
\text { Utrophin upregulated } \\
\text { Sarcoglycans reduced/absent } \\
\text { Dystroglycan reduced/absent } \\
\text { nNOS may be absent }\end{array}$ \\
\hline EDMD1 & $E M D$ & Emerin absent & \\
\hline LGMD1A MFM & MYOT & Myotilin cytoplasmic aggregates & $\begin{array}{l}\text { Desmin, } \alpha \text { B-crystallin, VCP cytoplasmic } \\
\text { aggregates }\end{array}$ \\
\hline $\begin{array}{l}\text { LGMD1B EDMD2 } \\
\text { EDMD3 }\end{array}$ & LMNA & Lamin A/C normally expressed & \\
\hline $\begin{array}{l}\text { LGMD1C rippling muscle } \\
\text { disease hyperCKemia }\end{array}$ & CAV3 & Caveolin-3 absent/reduced & Dysferlin reduced at the sarcolemma \\
\hline LGMD2A & CAPN3 & $\begin{array}{l}\text { Calpain } 3 \text { bands may be variably reduced on } \\
\text { immunoblot, labelling may be absent or reduced on } \\
\text { sections }\end{array}$ & Dysferlin reduced at the sarcolemma \\
\hline $\begin{array}{l}\text { LGMD2B Miyoshi } \\
\text { myopathy }\end{array}$ & DYSF & Dysferlin absent or very reduced & $\begin{array}{l}\text { Caveolin-3 reduced at the } \\
\text { sarcolemma, calpain } 3 \text { bands may be } \\
\text { reduced }\end{array}$ \\
\hline LGMD2C-F & $\begin{array}{l}\text { SGCG SGCA } \\
\text { SGCB } \\
\text { SGCD }\end{array}$ & Sarcoglycans variably reduced/absent & $\begin{array}{l}\beta \text {-Dystroglycan may be reduced } \\
\text { Dystrophin may be reduced } \\
\text { nNOS may be absent }\end{array}$ \\
\hline LGMD2G & TCAP & Telethonin absent & \\
\hline $\begin{array}{l}\text { LGMD21, K, M-O, DG- } \\
\text { pathies }\end{array}$ & $\begin{array}{l}\text { FKRP POMT1 FKTN } \\
\text { POMT2 POMGNT1 } \\
\text { LARGE }\end{array}$ & Not applicable & $\begin{array}{l}\text { Glycosylated } \alpha \text {-dystroglycan very } \\
\text { reduced/patchy } \\
\beta \text {-dystroglycan may be reduced } \\
\text { Laminin } \alpha 2 \text { may be reduced }\end{array}$ \\
\hline MDC1A & LAMA2 & Laminin $\alpha 2$ completely or partially absent & $\begin{array}{l}\text { Laminin } \alpha 5 \text { overall upregulated } \\
\alpha \text {-dystroglycan may be reduced }\end{array}$ \\
\hline $\begin{array}{l}\text { UCMD and Bethlem } \\
\text { myopathy }\end{array}$ & $\begin{array}{l}\text { COL6A1 COL6A2 } \\
\text { COL6A3 }\end{array}$ & $\begin{array}{l}\text { Collagen VI very reduced in UCMD, usually normally } \\
\text { expressed in BMD }\end{array}$ & \\
\hline MD with lipodystrophy & PTRF & PTRF-cavin absent/very reduced & Caveolin-3 reduced at the sarcolemma \\
\hline MFM & DES & Desmin cytoplasmic aggregates & $\begin{array}{l}\text { Myotilin, } \alpha \text { B-crystallin, VCP cytoplasmic } \\
\text { aggregates }\end{array}$ \\
\hline MFM & CRYAB & $\alpha B-C r y s t a l l i n$ cytoplasmic aggregates & $\begin{array}{l}\text { Myotilin, desmin, VCP cytoplasmic } \\
\text { aggregates }\end{array}$ \\
\hline IBMPFD & $V C P$ & VCP cytoplasmic aggregates & $\begin{array}{l}\text { Myotilin, desmin, } \alpha \text { B-crystallin } \\
\text { cytoplasmic aggregates }\end{array}$ \\
\hline
\end{tabular}

BMD = Becker muscular dystrophy; CK = creatine kinase; DG-pathies = dystroglycanopathies; DMD = Duchenne muscular dystrophy; EDMD = Emery-Dreifuss muscular dystrophy; IBMPFD = inclusion body myopathy with Paget's disease and frontotemporal dementia; LGMD = limb girdle muscular dystrophy; MD = muscular dystrophy; MDC = congenital muscular dystrophy; MFM = myofibrillar myopathy; nNOS = neuronal nitric oxide synthase; PTRF = polymerase I and transcript release factor; $\mathrm{UCMD}=$ Ulrich congenital muscular dystrophy; $\mathrm{VCP}=$ valosin-containing protein.

Disorders of the dystrophin glycoprotein complex Many of the MD types involve members of the DGC, a group of proteins that links the intracellular cytoskeleton and the extracellular matrix [12-15] (Figure 2). Dystroglycan $(\alpha-D G$ and $\beta-D G$ ) is the transmembrane axis that connects proteins of the extracellular matrix (for example, laminin-2) and dystrophin [12]. The dystrophin molecule has an N-terminal actin-binding domain followed by 24 repeat units (rod domain), a C-terminus that contains a cysteine-rich domain that binds to $\beta$-DG $[16,17]$ followed by a region that associates with dystrobrevin, syntrophins and, indirectly, with nNOS $[18,19]$. In skeletal muscle the DGC also contains four sarcoglycans $(\alpha, \beta, \gamma$ and $\delta$-SG) and sarcospan [20], all of which are 


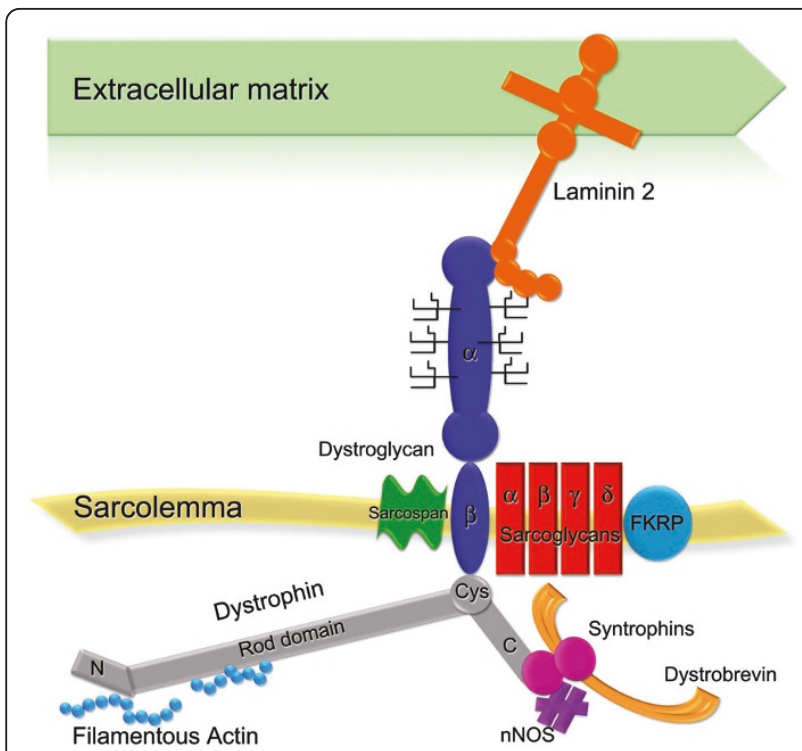

Figure 2 The dystrophin glycoprotein complex (DGC). Schematic representation of the core DGC and associated proteins.

encoded by different genes. One report also indicates that fukutin-related protein (FKRP) may be an integral component of the DGC [21]. Faults in components or ligands of the DGC complex (as observed in dystrophinopathy, sarcoglycanopathies, dystroglycanopathies and laminin $\alpha 2$ deficiency) cause disruption of the structural link that protects the muscle fibres from damage caused by contraction, and lead to muscular dystrophy [22].

\section{Dystrophinopathies}

Dystrophin is the product of the $D M D$ gene, located on the $\mathrm{X}$ chromosome. This is a very large gene with a high rate of new mutations with recessive inheritance pattern. Duchenne and Becker muscular dystrophies (DMD and BMD, respectively) are common in male patients, but symptomatic female carriers have also been described [23]. Due to the high incidence of dystrophinopathies compared with other forms of MD, ruling in or out DMD/BMD should always be the first diagnostic step. Deletions of the DMD gene account for $65 \%$ of cases and can be detected directly by molecular analysis. This test has eliminated the need for muscle biopsy in many cases of 'classic' dystrophinopathies but immunoanalysis still remains an important diagnostic tool $[24,25]$. Abnormal expression of dystrophin is the hallmark for the diagnosis of DMD/BMD. In general, severe mutations with disruption of the reading frame result in absence of dystrophin and cause DMD, while milder mutations with expression of dystrophin of reduced amount or variable mass cause BMD [26]. Due to the large size of dystrophin it is important to use ABs directed against several sites of the protein, to avoid false- negative results due to deletion of specific epitopes. A panel of ABs directed against $\mathrm{N}$-terminal, C-terminal and rod domain is routinely used in diagnostic laboratories. Western blotting should always be employed in parallel since it offers clues on the type of mutation present. In addition, quantification of the residual amount of dystrophin, if any, is useful for the prognosis of disease severity [27].

Total absence of dystrophin (Figure 1) or limited labelling on a very small proportion of revertant fibres [28] is specific for the diagnosis of DMD. In contrast, variation in dystrophin expression may be more subtle in patients with BMD. The use of an $A B$ panel for dystrophin is of particular diagnostic value in these cases. Although commercial ABs for dystrophin can detect abnormal protein with the most common in-frame deletions, absence of labelling for an $A B$ indicates deletion of that particular epitope. More frequently, in BMD the intensity of the labelling for one or more $A B$ is variable (Figure 3), but occasionally samples show levels of dystrophin similar to control on sections. Blotting of muscle is especially useful in these cases, however if the abnormality is very subtle, the diagnosis must rely on the assessment of secondary protein changes. Dystrophin expression is often abnormal in carriers of DMD, and its analysis is important in order to exclude differential diagnoses of autosomal MD. Due to a skewed pattern of X-inactivation in muscle, in transverse sections, both positive and negative fibres can be observed in variable proportion, which correlates with the severity of the phenotype $[29,30]$. Usually in these cases the immunoblot does not show abnormalities since the mutated dystrophin may be masked by the expression of the normal protein [31].

\section{Secondary protein changes}

There is value in including antibodies to other proteins as secondary markers in routine immunohistochemical studies for DMD and, especially, BMD. Utrophin, the dystrophin homolog encoded on chromosome 6 , is expressed in normal adult fibres only at the neuromuscular junction, but in DMD/BMD biopsies it is strongly upregulated at the sarcolemma [32]. As utrophin is also expressed in regenerating fibres [33], appropriate markers should be used to distinguish the abnormal from the normal expression (Figure 1). Utrophin is upregulated in most, but not all, cases of BMD [34], therefore it is important to examine the expression of other proteins when the diagnosis is not straightforward (Figure 3). Abnormal expression of dystrophin in DMD, BMD, and manifesting carriers is accompanied by a secondary reduction of other DGC proteins. Reduced labelling for sarcoglycans and $\alpha-D G$ and $\beta$-DG is common in dystrophinopathies [13-15,35]. Sarcolemmal nNOS is missing 


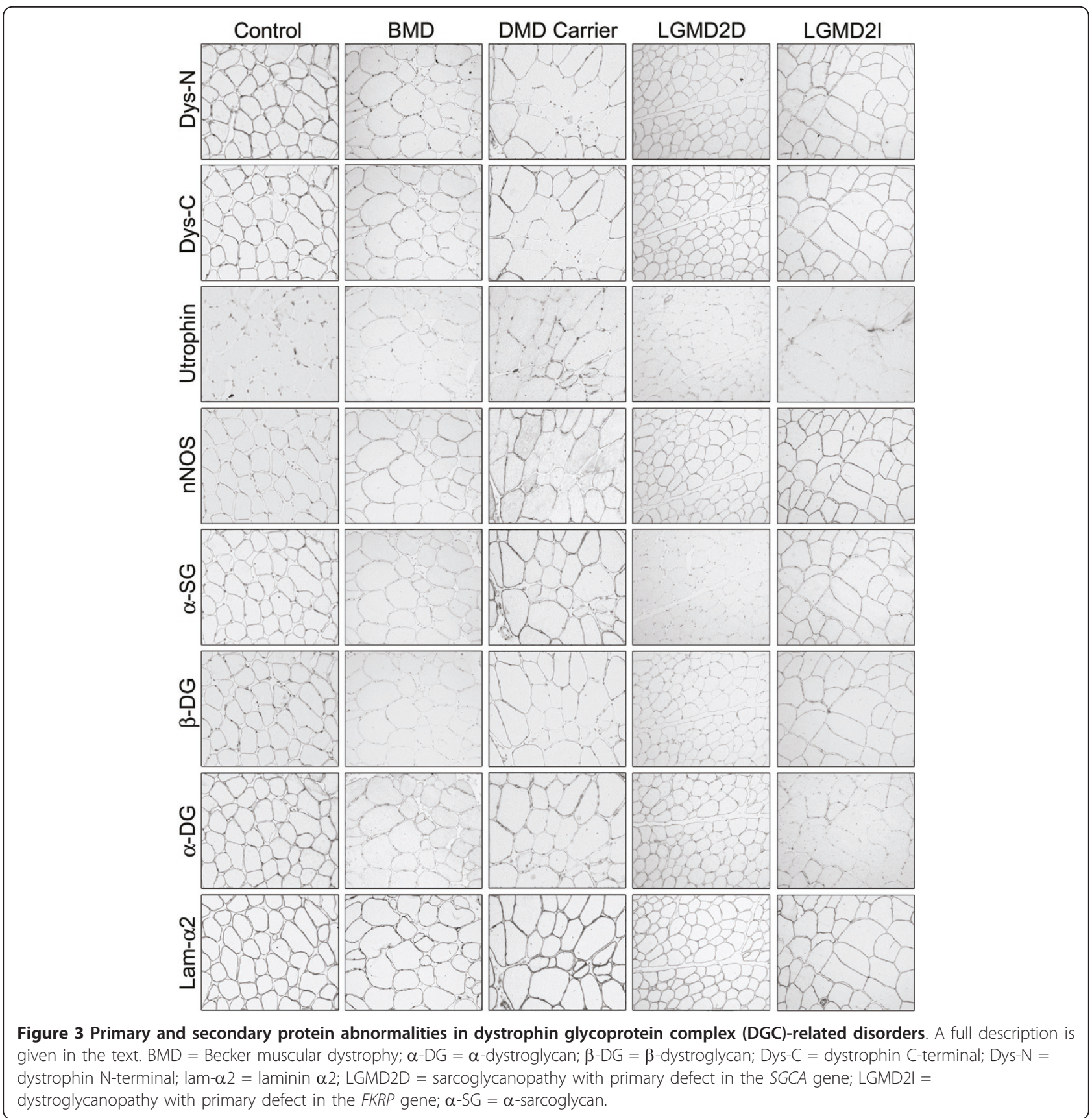

when dystrophin is absent or contains deletions in the mid-rod domain [36], but results have to be interpreted carefully since nNOS expression is very reduced in regenerating and denervated fibres [37].

\section{Limb girdle muscular dystrophy (LGMD)2C-F (sarcoglycanopathies)}

Primary defects responsible for MD have been found in genes encoding for $\alpha, \beta, \gamma$ and $\delta$-SG. These cause recessive LGMDs, now often referred to as the sarcoglycanopathies. The SGs act as a complex, such that a defect in any one leads to absence or reduction in expression of the other three SGs (Figure 3) [38]. However this is not a rigorous finding and labelling for all four proteins should be carried out to avoid misdiagnosing cases with selective loss of one SG [39]. The results from ABs to all four SGs are reliable in directing molecular analysis when the immunolabelling for one SG is absent or reduced and the expression of the others is retained $[38,40,41]$. However in most cases expression of all SGs can be variable and does not allow an accurate prediction of the genotype [42]. 


\section{Secondary protein changes}

The main clue to differentiate patients with sarcoglycanopathy from BMD or manifesting carriers is a pattern of reduced labelling for SGs in the presence of normal dystrophin (Figure 3). However, reports of sarcoglycanopathy biopsies with abnormal labelling of dystrophin and $\beta$-dystroglycan exist [41-43]. The abnormalities in these cases are mild than the defect in SGs expression [44]. In a male, if expression of all SGs and dystrophin is reduced it may be difficult to determine the primary defect without the aid of secondary protein abnormalities. Utrophin is usually not upregulated in LGMD2D-F patients. However, some cases of BMD may not show sarcolemmal utrophin (Figure 3), while occasional sarcoglycanopathies may show utrophin expression $[35,45]$. Loss of nNOS at the sarcolemma of patients with sarcoglycanopathies has been described [46,47] but the interpretation for diagnostic purposes is subject to the same limitations as for dystrophinopathies.

\section{Dystroglycanopathies}

The gene DAG1 encodes the propeptide that is proteolytically cleaved into two non-covalently associated proteins, $\alpha$-DG and $\beta$-DG $[48,49]$. Primary dystroglycanopathy, due to a defect in $D A G 1$, is very rare and has been described in only one patient to date [50]. Secondary dystroglycanopathies are more frequent and are caused by recessive mutations in at least six known or putative glycosyltransferases: FKRP, fukutin ( $F C M D)$, protein $O$-mannosyl transferase 1 (POMT1), protein $O$-mannosyl transferase 2 (POMT2), protein $O$-mannosyl $\beta-1,2-N$-acetylglucosaminyltransferase (POMGnT1), and LARGE [51,52]. Glycosylation is the crucial modification that modulates the function of $\alpha-D G$ as a receptor for extracellular binding partners [12]. Modifications in these genes result in abnormal glycosylation of $\alpha$-DG and lead to neuromuscular disorders that range from severe congenital onset with associated brain malformations (Walker-Warburg syndrome, muscle-eye-brain disease, Fukuyama muscular dystrophy), to milder forms of congenital muscular dystrophy (CMD) such as MDC1C and 1D, and to LGMD phenotypes (LGMD2I, $2 \mathrm{~K}, 2 \mathrm{M}, 2 \mathrm{~N}$, and 2O) [53-55]. Irrespective of the gene, all the mutations seem to act in a common pathway and the disease severity is possibly related to the impact of a particular mutation on DG function.

\section{Secondary protein changes}

$\mathrm{ABs}$ for most proteins involved are not currently in use for diagnosis. However abnormal labelling for $\alpha$-DG is common to all the dystroglycanopathies and it is an indicator that the mutation may reside in one of the six genes or in unknown genes in the same pathway. Glycosylation defects are revealed by loss or reduction of immunoreactivity to two ABs, VIA4 ${ }_{1}$ and IIH6, which recognise carbohydrate moieties of $\alpha$-DG (Figure 3) [56]. The extent of $\alpha-D G$ reduction can vary from severe to very subtle and can also be verified by immunoblot. While there is usually a good correlation between reduced $\alpha$-DG staining and phenotype in patients with mutations in POMT1, POMT2 and $P O M G n T 1$, this is not always true in patients with defects in FKRP and FCMD [57]. Notably, labelling for an $A B$ directed against a core peptide of $\alpha$-DG (GT20ADG) is usually well preserved on muscle fibres of dystroglycanopathy patients [56]. Consistently, this $\mathrm{AB}$ detects hypoglycosylated $\alpha$-DG with reduced molecular mass but at levels similar to control on immunoblot [56-58]. Variable reduction of laminin $\alpha 2$ labelling can occur, generally more evident on blot $[51,59,60]$. Laminin $\alpha 5$ is often overexpressed, although the finding is not consistent in all dystroglycanopathy patients (author's observation). $\beta$-DG may be mildly reduced on immunohistochemistry, but labelling on blot appears within the normal range [57]. Furthermore, one clinical report suggests that FKRP patients may have reduced expression of other DGC components [61].

\section{Congenital muscular dystrophy 1A (MDC1A, laminin $\alpha 2$ )}

Approximately $50 \%$ of patients with CMD show deficiency of laminin $\alpha 2$ expression in muscle [60]. Laminin $\alpha 2$, with the laminin chains $\beta 1$ and $\gamma 1$, is a component of laminin-2, the major constituent of the basal lamina of muscle fibres. Normal muscle shows uniform sarcolemmal immunolabelling; in cases of MDC1A laminin $\alpha 2$ may be absent or variably reduced [62]. Patients with a partial deficiency usually have a milder phenotype than those with absent or very reduced protein [60]. Laminin $\alpha 2$ is a large protein that on immunoblot appears as 80 and $300 \mathrm{kDa}$ fragments. It is good practice to assess sections of muscle biopsies with $\mathrm{ABs}$ to both fragments, particularly to diagnose cases with a partial reduction [5]. Indeed, cases with unremarkable labelling with the $80 \mathrm{kDa} A B$ may show a considerable reduction with the other $A B$ [63]. Laminin $\alpha 2$ is expressed in several tissues that can be used for diagnosis. In skin laminin $\alpha 2$ is localised to the epidermal/dermal junction and to the nerve endings of the arrector pili smooth muscle $[64,65]$. Prenatal testing can be carried out on chorionic villi from placentas of 8-23 weeks, which express most laminin chains [66]. The absence of laminin $\alpha 2$ is easily observed in these tissues, but cases with partial deficiency may be difficult to identify $[64,66,67]$.

\section{Secondary protein changes}

Upregulation of laminin $\alpha 5$ is observed in cases of total and partial laminin $\alpha 2$ deficiency [62]. This may be especially helpful for the diagnosis of cases with partial 
reduction, but caution is necessary since laminin $\alpha 5$ is normally present on immature and regenerating fibres. Reduction of $\alpha$-DG labelling may occur, which generates confusion in cases of partial laminin $\alpha 2$ deficiency [68].

\section{LGMD1A (myotilin) and myofibrillar myopathies}

Myotilin is a sarcomeric protein that is expressed at the $\mathrm{Z}$ line of skeletal muscle and is involved in the organisation and stabilisation of thin filaments and the sarcomere [69]. Mutations in the MYOT gene with LGMD1A phenotype have been identified in only two unrelated families [70,71], but the gene is also mutated in other forms of muscle disease such as myofibrillar myopathy (MFM), spheroid body myopathy, and late onset distal myopathy [72-74]. Signs of myotilinopathy include granular or hyaline accumulations that stain dark blue or red with Gomori trichrome (cytoplasmic bodies), vacuoles frequently rimmed by basophilic or red material with haematoxylin and eosin and Gomori trichrome, respectively, and streaming $\mathrm{Z}$ lines [72]. These structural abnormalities are also common features of the large group of MFMs [75], caused by mutations not only in MYOT but also in a number of other genes. MFM genes identified so far encode for desmin, $\alpha \mathrm{B}$-crystallin, $\mathrm{Z}$ band alternatively spliced PDZ-motif-containing protein (ZASP), filamin C, four-and-a-half LIM domain 1 (FHL1), BCL2-associated athanogene 3 (BAG3), and plectin (for review see [76]). This class of dominantly inherited diseases is difficult to differentiate based on histology only and clinical features are often better indicators of where the primary genetic defect may lie. Some histological findings can facilitate the diagnosis, for example spheroid bodies in Gomori trichrome stain may indicate a myotilinopathy or sarcoplasmic reducing bodies positive for menadione-NBT indicate FHL1opathy $[76,77]$. Antibodies directed against desmin, $\alpha \mathrm{B}$-crystallin and myotilin are good diagnostic tools to detect protein accumulation in MFM. However the number of affected fibres can be very variable, with some samples showing a large abundance and others only displaying a few abnormal fibres. Therefore protein tests may be unspecific or normal in genetically confirmed MFMs [76]. Furthermore, it must be kept in mind that minicores, central cores, and target fibres also show increased reactivity with these antibodies [76]. Accumulations of other sarcolemmal proteins such as dystrophin, SGs and caveolin-3 may also be seen in MFM [75]. Similar findings may be observed in biopsies from patients with valosin-containing protein (VCP)-related inclusion body myopathy associated with Paget's disease of bone and frontotemporal dementia which, therefore, should not be excluded as a differential diagnosis [78]. In summary, histology and immunoanalysis in the context of clinical data are useful to achieve a generic diagnosis for MFM, but immunolabelling is rarely conclusive in identifying the affected gene.

\section{LGMD1C (caveolin-3)}

Mutations in the CAV3 gene cause LGMD1C [79,80]. The muscle biopsies show a severe reduction of caveolin-3 at the sarcolemma. Caveolin-3 is localised at small invaginations of the plasma membrane (caveolae) and interacts with $\beta$-DG, but it is not an integral part of the DGC [81]. Mutations in CAV3 have also been found in hyperCKemia, distal myopathy, and rippling muscle disease, with many patients showing an overlap of the phenotypes. Although these disorders are mainly inherited in an autosomal dominant fashion, occasional autosomal recessive cases have been reported [82]. A mosaic pattern of reduction of caveolin-3 at the sarcolemma is detected in patients with immune-mediated rippling muscle disease (Figure 4). In these patients caveolin-3 may not be significantly reduced on blots [83]. More recently, secondary reduction of caveolin-3 at the sarcolemma has been described in patients with mutations in the gene encoding for polymerase I and transcript release factor (PTRF)-cavin, a caveolar-associated protein that plays a role in the formation of caveolae and the stabilisation of caveolins [84,85]. Abnormal localisation of dysferlin is often seen in muscle from patients with LGMD1C, indicating a structural or functional interaction between these proteins [86]. In the absence of caveolin-3, dysferlin accumulates in the cytoplasm and displays an irregular sarcolemmal distribution (Figure 4).

\section{LGMD2A (calpain 3)}

Calpain 3 (CAPN3), a muscle specific calcium-activated neutral protease, is the defective protein in LGMD2A [87]. Several cytoskeletal proteins are substrates for CAPN3, but this protein also displays autolytic activity and it is cleaved into a $\mathrm{N}$-terminal fragment of $30 \mathrm{kDa}$ and C-terminal fragments of 60 to $45 \mathrm{kDa}[88,89]$. Two ABs are mainly used for the detection of CAPN3 (Table $1)$. Until recently $[90,91]$, it was thought that these only work on immunoblot where they produce characteristic patterns of bands: full length CAPN3 (94 kDa), plus the additional degradation fragments (Figure 4 and data not shown) [92]. Immunocytochemical studies of CAPN3 are limited but promising, showing intracellular labelling with both ABs, which is absent in most LGMD2A patients $[90,91]$. Dysferlin membrane labelling may be secondarily reduced (Figure 4) [93].

Protein-based diagnosis for LGMD2A is not always fully reliable. Expression of full-length protein and degradation fragments has to be expertly evaluated to establish whether a defect is genuine or secondary. Indeed numerous factors influence the expression and 


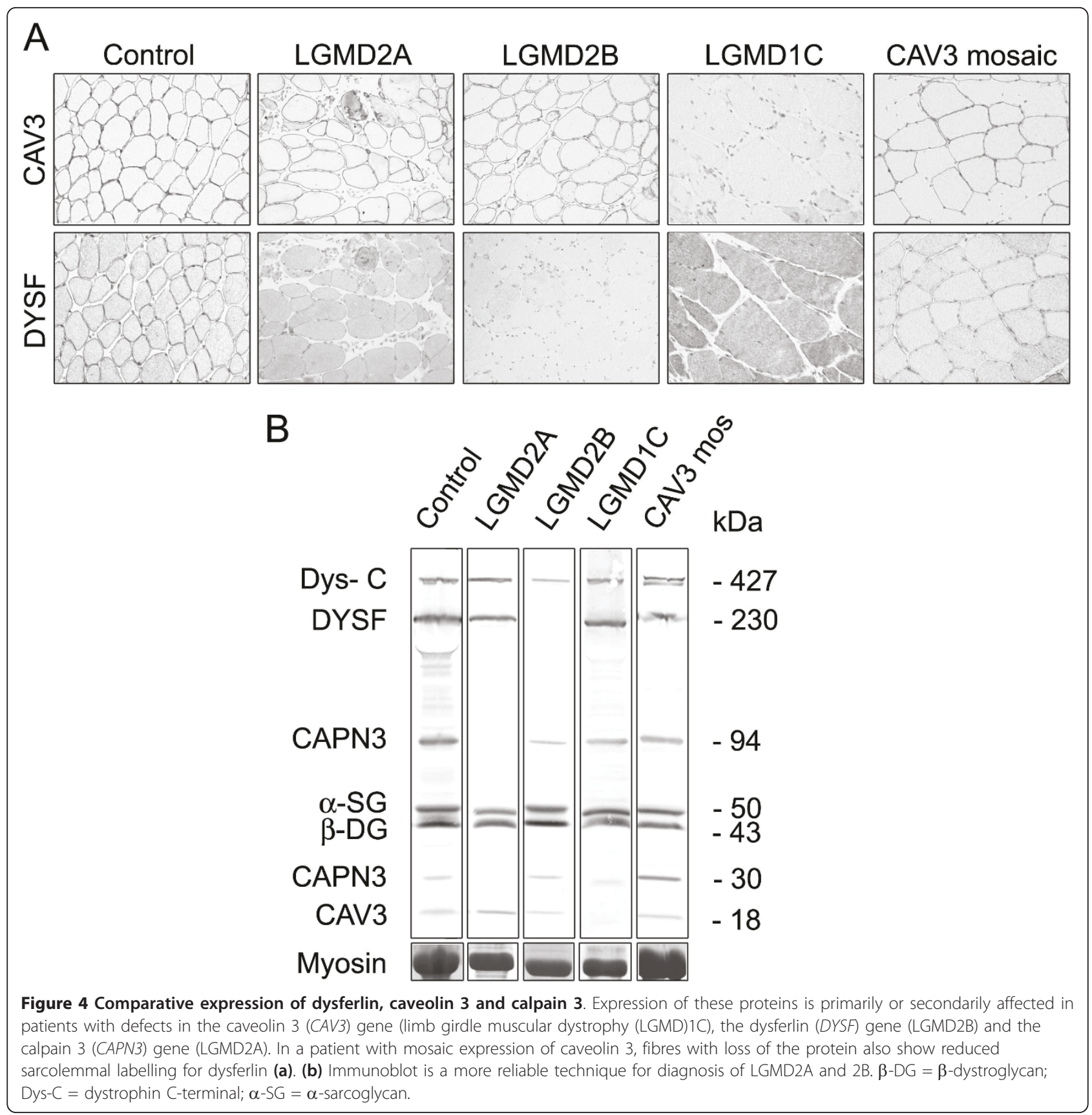

detection of CAPN3. Secondary deficiencies of CAPN3 have been described in several muscular dystrophies, including LGMD2B and LGMD2J [94,95]. Moreover, CAPN3 reduction is often observed in many dystrophic biopsies, perhaps as a consequence of rapid degradation and/or biopsy processing conditions [96]. In contrast, normal CAPN3 expression may be seen in patients with confirmed molecular diagnosis of LGMD2A [97]. Therefore data on CAPN3 expression must be interpreted by taking into account issues related to protein degradation and abnormalities of other LGMD proteins. For patients with a strong clinical suspicion for LGMD2A and normal CAPN3 expression the diagnosis relies on genetic analysis, but there is also value in using functional in vitro assays for the autolytic activity of CAPN3 [98].

\section{Dysferlinopathies}

Dysferlin is the product of the gene responsible for LGMD2B, Miyoshi myopathy and distal anterior compartment myopathy [99-101]. This protein is widely distributed, although it predominates in striated muscle where it localises to the sarcolemma and intracellular 
vesicles [102,103]. Primary defects in the DYSF gene lead to severely reduced protein expression and subsarcolemmal accumulation of vesicles [104]. CAPN3 and caveolin-3 are often secondarily reduced in LGMD2B (Figure 4) [105,106]. Secondary sarcolemmal reduction of dysferlin is often seen in muscle biopsies of patients with many other forms of muscular dystrophy but in all these cases the band for dysferlin is normally detected on immunoblot $[86,104,107,108]$. In contrast LGMD2B and Miyoshi myopathy patients typically show complete or partial absence of the dysferlin band on immunoblot of skeletal muscle (Figure 4b) or blood monocytes $[109,110]$. Some heterozygous carriers of LGMD2B also display reduced dysferlin levels, as well as variable muscle histopathological changes [111].

\section{LGMD2G (telethonin)}

LGMD2G is a rare condition described mainly in the Brazilian population [112,113] and it is associated with mutations in the gene for telethonin. Telethonin is a sarcomeric protein expressed at the $\mathrm{Z}$ line in skeletal and cardiac muscle, where it interacts with the C-terminal domain of titin $[69,114]$. Examination of muscle biopsies from affected individuals shows absence of telethonin and maintenance of the sarcomeric structure. All the other proteins involved in muscular dystrophies are normally expressed [114].

\section{Emery-Dreifuss muscular dystrophy (EDMD)}

Mutations in a number of genes are responsible for EDMD. Interestingly, all genes involved encode for proteins of the nuclear membrane. Both X-linked and autosomal forms have been described. EDMD1 is caused by mutations in the $E M D$ gene on the $\mathrm{X}$ chromosome that encodes for emerin [115]. Mutations occur throughout the gene and result in absence or mislocalisation of the protein $[116,117]$. In female carriers a variable number of emerin-positive and emerin-negative cells can be detected [118]. Emerin is ubiquitously expressed, and many tissues can be used as an alternative to muscle for protein studies. In particular skin and cells from buccal smears are frequently tested for diagnosis of X-linked EDMD patients and female carriers [119-121].

EDMD2 is due to mutations in the LMNA gene that encodes for lamins $A$ and $C$, intermediate filaments of the inner nuclear membrane in almost all cells. Mutations in LMNA can cause several different phenotypes including LGMD1B (for review see [122]). Inheritance is autosomal dominant, but very rare autosomal recessive cases (EDMD3) have been described [123]. Immunoanalysis in this type of disorder is not informative as no difference in the expression of lamin $\mathrm{A} / \mathrm{C}$ in skeletal muscle is detected due to the expression of the normal allele.
New mutations have been found in the synaptic nuclear envelope protein 1 (SYNE1) and in the synaptic nuclear envelope protein 2 (SYNE2) genes in two patients in two families, also called Nesprin-1 and Nesprin-2, but too few cases have been identified to know if immunolabelling has a role in diagnosis [124]. Mutations in the FHL1 gene have also been described in association with X-linked EDMD [125].

\section{Ullrich congenital muscular dystrophy (UCMD) and Bethlem myopathy (collagen VI)}

Collagen VI is a protein of the extracellular matrix, which consists of three $\alpha$ chains, $\alpha 1(\mathrm{VI}) \alpha 2(\mathrm{VI})$ and $\alpha 3$ (VI), encoded by the COL6A1, COL6A2 and COL6A3 genes, respectively. Mutations in all three genes have been reported in UCMD families [126-128] and in the milder Bethlem myopathy $[129,130]$. Collagen VI is present in most connective tissues and, in skeletal muscle, localises in the basement membrane, endomysium and perimysium. In the muscle of UCMD patients a spectrum of collagen VI anomalies can be found. The protein can be completely absent or the changes can be difficult to detect, with only absence at the basal lamina $[127,131]$. The subtle reduction makes it important to evaluate the results by double labelling with another antibody such as perlecan to verify the integrity of the basal lamina [5]. It must be noted that normal or nearly normal collagen VI immunolabelling does not exclude a diagnosis of UCMD [132]. In Bethlem myopathy, collagen VI immunolabelling of muscle is usually normal or shows very subtle alterations [133].

Several reports have described an absence or a reduction in the amount of secreted collagen VI in fibroblast cultures from UCMD patients $[128,134]$. This technique has a much higher predictive value of COL6A mutations in $\mathrm{BM}$ patients, since it allows detection of even very subtle alterations in collagen VI expression and secretion [133].

\section{Conclusions}

Protein analysis is the most valuable and dependable way of improving the efficiency of genetic testing in many types of MDs. Diagnosis is achieved in a significant proportion of patients when informative clinical data and immunoanalysis results are available to guide the molecular analysis [135]. The muscle biopsy is a time and cost-effective test for many muscle disorders with ambiguous presentation in part because of the limited capacity to screen for large and numerous genes simultaneously. When the primary genetic modification is unknown, immunoanalysis may be very useful to identify primary or secondary changes that highlight direct or functional protein interactions and guide the search for candidate genes. As molecular technologies are rapidly evolving, it is likely that in the near future 
low cost sequence for all MDs genes at once will be available. These advances will transform the diagnostic pathway for MDs and the diagnostic role of muscle biopsy may become less central. However, despite the availability of high throughput genetic tests, studies of protein expression in muscle biopsies will still be necessary for the diagnosis of MD. In fact, the effect of novel mutations is not always predictable and disruption or preservation of protein synthesis needs to be confirmed in the muscle. In addition protein analysis has important prognostic value, as seen for example in dystrophinopathies, where the residual amount of dystrophin correlates better with the phenotype than the genetic prediction [136]. Furthermore, tests on muscle biopsy remain crucial for evaluating the success of applied research and clinical trials such as gene therapies that aim to restore the missing protein.

\section{Acknowledgements}

The author wishes to thank the UK National Commissioning Group (NCG) for the support of the diagnostic work on rare neuromuscular diseases and the colleagues who have referred patients to the service. Expert technical assistance from Dr Richard Charlton, Mr Matt Henderson and Mrs Julie Marsh is gratefully acknowledged.

\section{Author details}

${ }^{1}$ NCG Diagnostic \& Advisory Service for Rare Neuromuscular Diseases, Muscle Immunoanalysis Unit, Dental Hospital, Richardson Road, Newcastle upon Tyne, UK. ${ }^{2}$ Newcastle University, Institute of Genetic Medicine, International Centre for Life, Central Parkway, Newcastle upon Tyne, UK.

\section{Competing interests}

The author declares that they have no competing interests.

Received: 18 February 2011 Accepted: 24 June 2011

Published: 24 June 2011

\section{References}

1. Gasper MC, Gilchrist JM: Creatine kinase: a review of its use in the diagnosis of muscle disease. Med Health R / 2005, 88:398, 400-394.

2. M Mercuri E, Bushby K, Ricci E, Birchall D, Pane M, Kinali M, Allsop J, Nigro V, Sáenz A, Nascimbeni A, Fulizio L, Angelini C, Muntoni F: Muscle MRI findings in patients with limb girdle muscular dystrophy with calpain 3 deficiency (LGMD2A) and early contractures. Neuromuscul Disord 2005, 15:164-171.

3. Fischer D, Walter MC, Kesper K, Petersen JA, Aurino S, Nigro V, Kubisch C, Meindl T, Lochmüller H, Wilhelm K, Urbach H, Schröder R: Diagnostic value of muscle MRI in differentiating LGMD2I from other LGMDs. J Neurol 2005, 252:538-547.

4. Mercuri E, Pichiecchio A, Allsop J, Messina S, Pane M, Muntoni F: Muscle MRI in inherited neuromuscular disorders: past, present, and future. $J$ Magn Reson Imaging 2007, 25:433-440.

5. Sewry CA: Muscular dystrophies: an update on pathology and diagnosis. Acta Neuropathol 2010, 120:343-358.

6. Bornemann A, Anderson LV: Diagnostic protein expression in human muscle biopsies. Brain Pathol 2000, 10:193-214.

7. Anderson LV, Davison K: Multiplex western blotting system for the analysis of muscular dystrophy proteins. Am J Pathol 1999, 154:1017-1022

8. Heckmatt JZ, Leeman S, Dubowitz V: Ultrasound imaging in the diagnosis of muscle disease. J Pediatr 1982, 101:656-660.

9. Patton BL, Connoll AM, Martin PT, Cunningham JM, Mehta S, Pestronk A, Miner JH, Sanes JR: Distribution of ten laminin chains in dystrophic and regenerating muscles. Neuromuscul Disord 1999, 9:423-433.
10. Sewry C, Dubowitz V: Immunohistochemistry. Muscle Biopsy: a Practical Approach. 3 edition. St. Louis, MO: Saunders Elsevier; 2007, 195-245.

11. Klinge L, Harris J, Sewry C, Charlton R, Anderson L, Laval S, Chiu YH, Hornsey M, Straub V, Barresi R, Lochmüller H, Bushby K: Dysferlin associates with the developing T-tubule system in rodent and human skeletal muscle. Muscle Nerve 2010, 41:166-173.

12. Barresi R, Campbell KP: Dystroglycan: from biosynthesis to pathogenesis of human disease. J Cell Sci 2006, 119:199-207.

13. Lim LE, Campbell KP: The sarcoglycan complex in limb-girdle muscular dystrophy. Curr Opin Neurol 1998, 11:443-452.

14. Ozawa E, Noguchi S, Mizuno Y, Hagiwara Y, Yoshida M: From dystrophinopathy to sarcoglycanopathy: evolution of a concept of muscular dystrophy. Muscle Nerve 1998, 21:421-438.

15. Straub V, Campbell KP: Muscular dystrophies and the dystrophinglycoprotein complex. Curr Opin Neurol 1997, 10:168-175.

16. Jung D, Yang B, Meyer J, Chamberlain JS, Campbell KP: Identification and characterization of the dystrophin anchoring site on beta-dystroglycan. $J$ Biol Chem 1995, 270:27305-27310.

17. Suzuki A, Yoshida M, Yamamoto H, Ozawa E: Glycoprotein-binding site of dystrophin is confined to the cysteine-rich domain and the first half of the carboxy-terminal domain. FEBS Lett 1992, 308:154-160.

18. Sadoulet-Puccio HM, Rajala M, Kunkel LM: Dystrobrevin and dystrophin: an interaction through coiled-coil motifs. Proc Natl Acad Sci USA 1997, 94:12413-12418.

19. Suzuki A, Yoshida M, Ozawa E: Mammalian a1- and $\beta 1$-syntrophin bind to the alternative splice-prone region of the dystrophin $\mathrm{COOH}$ terminus. $J$ Cell Biol 1995, 128:373-381.

20. Crosbie RH, Heighway J, Venzke DP, Lee JC, Campbell KP: Sarcospan, the $25-\mathrm{kDa}$ transmembrane component of the dystrophin-glycoprotein complex. J Biol Chem 1997, 272:31221-31224.

21. Beedle AM, Nienaber PM, Campbell KP: Fukutin-related protein associates with the sarcolemmal dystrophin-glycoprotein complex. J Biol Chem 2007.

22. Ervasti JM, Campbell KP: Membrane organization of the dystrophinglycoprotein complex. Cell 1991, 66:1121-1131.

23. Arahata K, Ishihara T, Kamakura K, Tsukahara T, Ishiura S, Baba C, Matsumoto T, Nonaka I, Sugita H: Mosaic expression of dystrophin in symptomatic carriers of Duchenne's muscular dystrophy. New Engl J Med 1989, 320(3):138-142

24. Tuffery-Giraud S, Saquet C, Chambert S, Echenne B, Marie Cuisset J, Rivier F, Cossée M, Philippe C, Monnier N, Bieth E, Recan D, Antoinette Voelckel M,

Perelman S, Lambert JC, Malcolm S, Claustres M: The role of muscle biopsy in analysis of the dystrophin gene in Duchenne muscular dystrophy: experience of a national referral centre. Neuromuscul Disord 2004, 14:650-658.

25. Deburgrave N, Daoud F, Llense S, Barbot JC, Récan D, Peccate C, Burghes AH, Béroud C, Garcia L, Kaplan JC, Chelly J, Leturcq F: Protein- and mRNA-based phenotype-genotype correlations in DMD/BMD with point mutations and molecular basis for BMD with nonsense and frameshift mutations in the DMD gene. Hum Mutat 2007, 28:183-195.

26. Muntoni F, Torelli S, Ferlini A: Dystrophin and mutations: one gene, several proteins, multiple phenotypes. Lancet Neurol 2003, 2:731-740.

27. Nicholson LV, Johnson MA, Bushby KM, Gardner-Medwin D, Curtis A, Ginjaar IB, den Dunnen JT, Welch JL, Butler TJ, Bakker E: Integrated study of 100 patients with Xp21 linked muscular dystrophy using clinical, genetic, immunochemical, and histopathological data. Part 3. Differential diagnosis and prognosis. J Med Genet 1993, 30:745-751.

28. Thanh LT, Man NT, Hori S, Sewry CA, Dubowitz V, Morris GE: Characterization of genetic deletions in Becker muscular dystrophy using monoclonal antibodies against a deletion-prone region of dystrophin. Am J Med Genet 1995, 58:177-186.

29. Clerk A, Rodillo E, Heckmatt JZ, Dubowitz V, Strong PN, Sewry CA: Characterisation of dystrophin in carriers of Duchenne muscular dystrophy. J Neurol Sci 1991, 102:197-205.

30. Sewry CA, Matsumura K, Campbell KP, Dubowitz V: Expression of dystrophin-associated glycoproteins and utrophin in carriers of Duchenne muscular dystrophy. Neuromuscul Disord 1994, 4:401-409.

31. Clerk A, Rodillo E, Heckmatt JZ, Dubowitz V, Strong PN, Sewry CA: Characterisation of dystrophin in carriers of Duchenne muscular dystrophy. J Neurol Sci 1991, 102:197-205. 
32. Mizuno Y, Nonaka I, Hirai S, Ozawa E: Reciprocal expression of dystrophin and utrophin in muscles of Duchenne muscular dystrophy patients, female DMD-carriers and control subjects. J Neurol Sci 1993, 119:43-52.

33. Sewry CA, Nowak KJ, Ehmsen JT, Davies KE: A and B utrophin in human muscle and sarcolemmal A-utrophin associated with tumours. Neuromuscul Disord 2005, 15:779-785.

34. Taylor J, Muntoni F, Dubowitz V, Sewry CA: The abnormal expression of utrophin in Duchenne and Becker muscular dystrophy is age related. Neuropathol Appl Neurobiol 1997, 23:399-405.

35. Sewry CA, Sansome A, Matsumura K, Campbell KP, Dubowitz V: Deficiency of the $50 \mathrm{kDa}$ dystrophin-associated glycoprotein and abnormal expression of utrophin in two south Asian cousins with variable expression of severe childhood autosomal recessive muscular dystrophy. Neuromuscul Disord 1994, 4:121-129.

36. Torelli S, Brown SC, Jimenez-Mallebrera C, Feng L, Muntoni F, Sewry CA: Absence of neuronal nitric oxide synthase ( $\mathrm{nNOS}$ ) as a pathological marker for the diagnosis of Becker muscular dystrophy with rod domain deletions. Neuropathol Appl Neurobiol 2004, 30:540-545.

37. Tews DS, Goebel HH, Schneider I, Gunkel A, Stennert E, Neiss WF: Expression of different isoforms of nitric oxide synthase in experimentally denervated and reinnervated skeletal muscle. $J$ Neuropathol Exp Neurol 1997, 56:1283-1289.

38. Sewry CA, Taylor J, Anderson LV, Ozawa E, Pogue R, Piccolo F, Bushby K, Dubowitz $V$, Muntoni F: Abnormalities in alpha-, beta- and gammasarcoglycan in patients with limb-girdle muscular dystrophy. Neuromuscul Disord 1996, 6:467-474.

39. Anderson LV: Optimized protein diagnosis in the autosomal recessive limb-girdle muscular dystrophies. Neuromuscul Disord 1996, 6:443-446.

40. Bonnemann CG, Wong J, Jones KJ, Lidov HG, Feener CA, Shapiro F, Darras BT, Kunkel LM, North KN: Primary gamma-sarcoglycanopathy (LGMD 2C): broadening of the mutational spectrum guided by the immunohistochemical profile. Neuromuscul Disord 2002, 12:273-280.

41. Vainzof M, Passos-Bueno MR, Canovas M, Moreira ES, Pavanello RC, Marie SK, Anderson LV, Bonnemann CG, McNally EM, Nigro V, Kunkel LM, Zatz M: The sarcoglycan complex in the six autosomal recessive limbgirdle muscular dystrophies. Hum Mol Genet 1996, 5:1963-1969.

42. Klinge L, Dekomien G, Aboumousa A, Charlton R, Epplen JT, Barresi R, Bushby K, Straub V: Sarcoglycanopathies: can muscle immunoanalysis predict the genotype? Neuromuscul Disord 2008, 18:934-941.

43. Jones KJ, Kim SS, North KN: Abnormalities of dystrophin, the sarcoglycans, and laminin alpha2 in the muscular dystrophies. J Med Genet 1998, 35:379-386.

44. Pogue R, Anderson LV, Pyle A, Sewry C, Pollitt C, Johnson MA, Davison K, Moss JA, Mercuri E, Muntoni F, Bushby KM: Strategy for mutation analysis in the autosomal recessive limb-girdle muscular dystrophies. Neuromuscul Disord 2001, 11:80-87.

45. Sewry CA: Immunocytochemical analysis of human muscular dystrophy. Microsc Res Tech 2000, 48:142-154.

46. Crosbie RH, Barresi R, Campbell KP: Loss of sarcolemma nNOS in sarcoglycan-deficient muscle. FASEB J 2002, 16:1786-1791.

47. Kobayashi YM, Rader EP, Crawford RW, lyengar NK, Thedens DR, Faulkner JA, Parikh SV, Weiss RM, Chamberlain JS, Moore SA, Campbell KP: Sarcolemma-localized nNOS is required to maintain activity after mild exercise. Nature 2008, 456:511-515.

48. Ibraghimov-Beskrovnaya O, Milatovich A, Ozcelik T, Yang B, Koepnick K, Francke U, Campbell KP: Human dystroglycan: skeletal muscle cDNA, genomic structure, origin of tissue specific isoforms and chromosomal localization. Hum Mol Genet 1993, 2:1651-1657.

49. Holt KH, Crosbie RH, Venzke DP, Campbell KP: Biosynthesis of dystroglycan: processing of a precursor propeptide. FEBS Lett 2000, 468:79-83.

50. Hara Y, Balci-Hayta B, Yoshida-Moriguchi T, Kanagawa M, Beltrán-Valero de Bernabé D, Gündeşli H, Willer T, Satz JS, Crawford RW, Burden SJ, Kunz S, Oldstone MB, Accardi A, Talim B, Muntoni F, Topaloğlu H, Dinçer P, Campbell KP: A dystroglycan mutation associated with limb-girdle muscular dystrophy. N Engl J Med 2011, 364:939-946.

51. Brockington M, Blake DJ, Prandini P, Brown SC, Torelli S, Benson MA Ponting CP, Estournet B, Romero NB, Mercuri E, Voit T, Sewry CA, Guicheney $P$, Muntoni F: Mutations in the fukutin-related protein gene (FKRP) cause a form of congenital muscular dystrophy with secondary laminin alpha2 deficiency and abnormal glycosylation of alphadystroglycan. Am J Hum Genet 2001, 69:1198-1209.

52. Brockington M, Yuva Y, Prandini P, Brown SC, Torelli S, Benson MA, Herrmann R, Anderson LV, Bashir R, Burgunder JM, Fallet S, Romero N, Fardeau M, Straub V, Storey G, Pollitt C, Richard I, Sewry CA, Bushby K, Voit T, Blake DJ, Muntoni F: Mutations in the fukutin-related protein gene (FKRP) identify limb girdle muscular dystrophy $2 \mathrm{l}$ as a milder allelic variant of congenital muscular dystrophy MDC1C. Hum Mol Genet 2001, 10:2851-2859.

53. Godfrey C, Clement E, Mein R, Brockington M, Smith J, Talim B, Straub V, Robb S, Quinlivan R, Feng L, Jimenez-Mallebrera C, Mercuri E, Manzur AY, Kinali M, Torelli S, Brown SC, Sewry CA, Bushby K, Topaloglu H, North K, Abbs S, Muntoni F: Refining genotype phenotype correlations in muscular dystrophies with defective glycosylation of dystroglycan. Brain 2007, 130:2725-2735.

54. Muntoni F, Torelli S, Brockington M: Muscular dystrophies due to glycosylation defects. Neurotherapeutics 2008, 5:627-632.

55. Hewitt JE: Abnormal glycosylation of dystroglycan in human genetic disease. Biochim Biophys Acta 2009, 1792:853-861.

56. Michele DE, Barresi R, Kanagawa M, Saito F, Cohn RD, Satz JS, Dollar J, Nishino I, Kelley RI, Somer H, Straub V, Mathews KD, Moore SA, Campbell KP: Post-translational disruption of dystroglycan-ligand interactions in congenital muscular dystrophies. Nature 2002, 418:417-422.

57. Jimenez-Mallebrera C, Torelli S, Feng L, Kim J, Godfrey C, Clement E, Mein R, Abbs S, Brown SC, Campbell KP, Kröger S, Talim B, Topaloglu H, Quinlivan R, Roper H, Childs AM, Kinali M, Sewry CA, Muntoni F: A comparative study of alpha-dystroglycan glycosylation in dystroglycanopathies suggests that the hypoglycosylation of alpha-dystroglycan does not consistently correlate with clinical severity. Brain Pathol 2009, 19:596-611.

58. Kim DS, Hayashi YK, Matsumoto H, Ogawa M, Noguchi S, Murakami N Sakuta R, Mochizuki M, Michele DE, Campbell KP, Nonaka I, Nishino I: POMT1 mutation results in defective glycosylation and loss of lamininbinding activity in alpha-DG. Neurology 2004, 62:1009-1011.

59. Longman C, Brockington M, Torelli S, Jimenez-Mallebrera C, Kennedy C, Khalil N, Feng L, Saran RK, Voit T, Merlini L, Sewry CA, Brown SC, Muntoni F: Mutations in the human LARGE gene cause MDC1D, a novel form of congenital muscular dystrophy with severe mental retardation and abnormal glycosylation of alpha-dystroglycan. Hum Mol Genet 2003.

60. Sewry CA, Muntoni F: Inherited disorders of the extracellular matrix. Curr Opin Neurol 1999, 12:519-526.

61. Macleod H, Pytel P, Wollmann R, Chelmicka-Schorr E, Silver K, Anderson RB, Waggoner D, McNally EM: A novel FKRP mutation in congenital muscular dystrophy disrupts the dystrophin glycoprotein complex. Neuromuscul Disord 2007, 17:285-289.

62. Sewry CA, Philpot J, Mahony D, Wilson LA, Muntoni F, Dubowitz V: Expression of laminin subunits in congenital muscular dystrophy. Neuromuscul Disord 1995, 5:307-316.

63. Sewry CA, Naom I, D'Alessandro M, Sorokin L, Bruno S, Wilson LA, Dubowitz $V$, Muntoni F: Variable clinical phenotype in merosin-deficient congenital muscular dystrophy associated with differential immunolabelling of two fragments of the laminin alpha 2 chain. Neuromuscul Disord 1997, 7:169-175.

64. Sewry CA, D'Alessandro M, Wilson LA, Sorokin LM, Naom I, Bruno S, Ferlini A, Dubowitz V, Muntoni F: Expression of laminin chains in skin in merosin-deficient congenital muscular dystrophy. Neuropediatrics 1997, 28:217-222.

65. Marbini A, Bellanova MF, Ferrari A, Lodesani M, Gemignani F: Immunohistochemical study of merosin-negative congenital muscular dystrophy: laminin alpha 2 deficiency in skin biopsy. Acta Neuropathologica 1997, 94:103-108.

66. Naom I, Sewry C, D'Alessandro M, Topaloglu H, Ferlini A, Wilson L, Dubowitz V, Muntoni F: Prenatal diagnosis in merosin-deficient congenital muscular dystrophy. Neuromuscul Disord 1997, 7:176-179.

67. Jimenez-Mallebrera C, Brown SC, Sewry CA, Muntoni F: Congenital muscular dystrophy: molecular and cellular aspects. Cell Mol Life Sci 2005, 62:809-823.

68. Muntoni F, Brockington M, Godfrey C, Ackroyd M, Robb S, Manzur A, Kinali M, Mercuri E, Kaluarachchi M, Feng L, Jimenez-Mallebrera C, Clement E, Torelli S, Sewry CA, Brown SC: Muscular dystrophies due to defective glycosylation of dystroglycan. Acta Myol 2007, 26:129-135. 
69. Faulkner G, Lanfranchi G, Valle G: Telethonin and other new proteins of the Z-disc of skeletal muscle. IUBMB Life 2001, 51:275-282.

70. Hauser MA, Conde CB, Kowaljow V, Zeppa G, Taratuto AL, Torian UM, Vance J, Pericak-Vance MA, Speer MC, Rosa AL: Myotilin mutation found in second pedigree with LGMD1A. Am J Hum Genet 2002, 71:1428-1432.

71. Hauser MA, Horrigan SK, Salmikangas P, Torian UM, Viles KD, Dancel R, Tim RW, Taivainen A, Bartoloni L, Gilchrist JM, Stajich JM, Gaskell PC Gilbert JR, Vance JM, Pericak-Vance MA, Carpen O, Westbrook CA, Speer MC: Myotilin is mutated in limb girdle muscular dystrophy $1 \mathrm{~A}$. Hum Mol Genet 2000, 9:2141-2147.

72. Selcen D, Engel AG: Mutations in myotilin cause myofibrillar myopathy. Neurology 2004, 62:1363-1371.

73. Foroud T, Pankratz N, Batchman AP, Pauciulo MW, Vidal R, Miravalle $L$, Goebel HH, Cushman LJ, Azzarelli B, Horak H, Farlow M, Nichols WC: A mutation in myotilin causes spheroid body myopathy. Neurology 2005, 65:1936-1940.

74. Penisson-Besnier I, Talvinen K, Dumez C, Vihola A, Dubas F, Fardeau M, Hackman P, Carpen O, Udd B: Myotilinopathy in a family with late onset myopathy. Neuromuscul Disord 2006, 16:427-431.

75. Selcen D, Ohno K, Engel AG: Myofibrillar myopathy: clinical, morphological and genetic studies in 63 patients. Brain 2004, 127:439-451.

76. Schroder R, Schoser B: Myofibrillar myopathies: a clinical and myopathological guide. Brain Pathol 2009, 19:483-492.

77. Schessl J, Taratuto AL, Sewry C, Battini R, Chin SS, Maiti B, Dubrovsky AL, Erro MG, Espada G, Robertella M, Saccoliti M, Olmos P, Bridges LR, Standring P, Hu Y, Zou Y, Swoboda KJ, Scavina M, Goebel HH, Mitchell CA, Flanigan KM, Muntoni F, Bönnemann CG: Clinical, histological and genetic characterization of reducing body myopathy caused by mutations in FHL1. Brain 2009, 132:452-464.

78. Hübbers CU, Clemen CS, Kesper K, Böddrich A, Hofmann A, Kämäräinen O, Tolksdorf K, Stumpf M, Reichelt J, Roth U, Krause S, Watts G, Kimonis V, Wattjes MP, Reimann J, Thal DR, Biermann K, Evert BO, Lochmüller $\mathrm{H}$, Wanker EE, Schoser BG, Noegel AA, Schröder R: Pathological consequences of VCP mutations on human striated muscle. Brain 2007, 130:381-393.

79. McNally EM, de Sá Moreira E, Duggan DJ, Bönnemann CG, Lisanti MP, Lidov HG, Vainzof M, Passos-Bueno MR, Hoffman EP, Zatz M, Kunkel LM: Caveolin-3 in muscular dystrophy. Hum Mol Genet 1998, 7:871-877.

80. Minetti C, Sotgia F, Bruno C, Scartezzini P, Broda P, Bado M, Masetti E, Mazzocco M, Egeo A, Donati MA, Volonte D, Galbiati F, Cordone G, Bricarelli FD, Lisanti MP, Zara F: Mutations in the caveolin-3 gene cause autosomal dominant limb-girdle muscular dystrophy. Nat Genet 1998, 18:365-368.

81. Crosbie RH, Yamada H, Venzke DP, Lisanti MP, Campbell KP: Caveolin-3 is not an integral component of the dystrophin glycoprotein complex. FEBS Lett 1998, 427:279-282.

82. Gazzerro E, Sotgia F, Bruno C, Lisanti MP, Minetti C: Caveolinopathies: from the biology of caveolin-3 to human diseases. Eur J Hum Genet 2010, 18:137-145

83. Schoser B, Jacob S, Hilton-Jones D, Müller-Felber W, Kubisch C, Claus D, Goebel HH, Vita G, Vincent A, Toscano A, Van den Bergh P: Immunemediated rippling muscle disease with myasthenia gravis: a report of seven patients with long-term follow-up in two. Neuromuscul Disord 2009, 19:223-228.

84. Hayashi YK, Matsuda C, Ogawa M, Goto K, Tominaga K, Mitsuhashi S, Park YE, Nonaka I, Hino-Fukuyo N, Haginoya K, Sugano H, Nishino I: Human PTRF mutations cause secondary deficiency of caveolins resulting in muscular dystrophy with generalized lipodystrophy. J Clin Invest 2009, 119:2623-2633.

85. Rajab A, Straub V, McCann LJ, Seelow D, Varon R, Barresi R, Schulze A, Lucke B, Lützkendorf S, Karbasiyan M, Bachmann S, Spuler S, Schuelke M: Fatal cardiac arrhythmia and long-QT syndrome in a new form of congenital generalized lipodystrophy with muscle rippling (CGL4) due to PTRF-CAVIN mutations. PLoS Genet 2010, 6:e1000874

86. Matsuda C, Hayashi YK, Ogawa M, Aoki M, Murayama K, Nishino I, Nonaka I, Arahata K, Brown RH Jr: The sarcolemmal proteins dysferlin and caveolin3 interact in skeletal muscle. Hum Mol Genet 2001, 10:1761-1766.

87. Richard I, Broux O, Allamand V, Fougerousse F, Chiannilkulchai N, Bourg N, Brenguier L, Devaud C, Pasturaud P, Roudaut C, Hillaire D, PassosBueno MR, Zatz M, Tischfield JA, Fardeau M, Jackson CE, Cohen D,
Beckmann JS: Mutations in the proteolytic enzyme calpain 3 cause limbgirdle muscular dystrophy type 2A. Cell 1995, 81:27-40.

88. Anderson LV, Davison K, Moss JA, Richard I, Fardeau M, Tome FM, Hubner C, Lasa A, Colomer J, Beckmann JS: Characterization of monoclonal antibodies to calpain 3 and protein expression in muscle from patients with limb-girdle muscular dystrophy type 2A. Am J Pathol 1998, 153:1169-1179.

89. Taveau M, Bourg N, Sillon G, Roudaut C, Bartoli M, Richard I: Calpain 3 is activated through autolysis within the active site and lyses sarcomeric and sarcolemmal components. Mol Cell Biol 2003, 23:9127-9135.

90. Charlton R, Henderson M, Richards J, Hudson J, Straub V, Bushby K, Barresi R: Immunohistochemical analysis of calpain 3: advantages and limitations in diagnosing LGMD2A. Neuromuscul Disord 2009, 19:449-457.

91. Kolski HK, Hawkins C, Zatz M, de Paula F, Biggar D, Alman B, Vajsar J: Diagnosis of limb-girdle muscular dystrophy $2 \mathrm{~A}$ by immunohistochemical techniques. Neuropathology 2008, 28:264-268.

92. Anderson LV, Davison K, Moss JA, Richard I, Fardeau M, Tome FM, Hubner C, Lasa A, Colomer J, Beckmann JS: Characterization of monoclonal antibodies to calpain 3 and protein expression in muscle from patients with limb-girdle muscular dystrophy type $2 \mathrm{~A}$. Am J Pathol 1998, 153:1169-1179.

93. Vainzof M, Anderson LV, McNally EM, Davis DB, Faulkner G, Valle G, Moreira ES, Pavanello RC, Passos-Bueno MR, Zatz M: Dysferlin protein analysis in limb-girdle muscular dystrophies. J Mol Neurosci 2001, 17:71-80.

94. A Anderson LV, Harrison RM, Pogue R, Vafiadaki E, Pollitt C, Davison K, Moss JA, Keers S, Pyle A, Shaw PJ, Mahjneh I, Argov Z, Greenberg CR, Wrogemann K, Bertorini T, Goebel HH, Beckmann JS, Bashir R, Bushby KM: Secondary reduction in calpain 3 expression in patients with limb girdle muscular dystrophy type $2 \mathrm{~B}$ and Miyoshi myopathy (primary dysferlinopathies). Neuromuscul Disord 2000, 10:553-559.

95. Haravuori H, Vihola A, Straub V, Auranen M, Richard I, Marchand S, Voit T, Labeit S, Somer H, Peltonen L, Beckmann JS, Udd B: Secondary calpain3 deficiency in 2q-linked muscular dystrophy: titin is the candidate gene. Neurology 2001, 56:869-877.

96. Sorimachi H, Toyama-Sorimachi N, Saido TC, Kawasaki H, Sugita H, Miyasaka M, Arahata K, Ishiura S, Suzuki K: Muscle-specific calpain, p94, is degraded by autolysis immediately after translation, resulting in disappearance from muscle. J Biol Chem 1993, 268:10593-10605.

97. Groen EJ, Charlton R, Barresi R, Anderson LV, Eagle M, Hudson J, Koref MS, Straub V, Bushby KM: Analysis of the UK diagnostic strategy for limb girdle muscular dystrophy 2A. Brain 2007, 130:3237-3249.

98. Fanin M, Nascimbeni AC, Fulizio L, Trevisan CP, Meznaric-Petrusa M, Angelini C: Loss of calpain-3 autocatalytic activity in LGMD2A patients with normal protein expression. Am J Pathol 2003, 163:1929-1936.

99. Bashir R, Britton S, Strachan T, Keers S, Vafiadaki E, Lako M, Richard I, Marchand S, Bourg N, Argov Z, Sadeh M, Mahjneh I, Marconi G, PassosBueno MR, Moreira Ede S, Zatz M, Beckmann JS, Bushby K: A gene related to Caenorhabditis elegans spermatogenesis factor fer-1 is mutated in limb-girdle muscular dystrophy type 2B. Nat Genet 1998, 20:37-42.

100. Liu J, Aoki M, Illa I, Wu C, Fardeau M, Angelini C, Serrano C, Urtizberea JA, Hentati F, Hamida MB, Bohlega S, Culper EJ, Amato AA, Bossie K, Oeltjen J, Bejaoui K, McKenna-Yasek D, Hosler BA, Schurr E, Arahata K, de Jong PJ, Brown RH Jr: Dysferlin, a novel skeletal muscle gene, is mutated in Miyoshi myopathy and limb girdle muscular dystrophy. Nat Genet 1998, 20:31-36.

101. Illa I, Serrano-Munuera C, Gallardo E, Lasa A, Rojas-Garcia R, Palmer J, Gallano P, Baiget M, Matsuda C, Brown RH: Distal anterior compartment myopathy: a dysferlin mutation causing a new muscular dystrophy phenotype. Ann Neurol 2001, 49:130-134.

102. Bansal D, Miyake K, Vogel SS, Groh S, Chen CC, Williamson R, McNeil PL, Campbell KP: Defective membrane repair in dysferlin-deficient muscular dystrophy. Nature 2003, 423:168-172.

103. Han R, Bansal D, Miyake K, Muniz VP, Weiss RM, McNeil PL, Campbell KP. Dysferlin-mediated membrane repair protects the heart from stressinduced left ventricular injury. J Clin Invest 2007, 117:1805-1813.

104. Piccolo F, Moore SA, Ford GC, Campbell KP: Intracellular accumulation and reduced sarcolemmal expression of dysferlin in limb-girdle muscular dystrophies. Ann Neurol 2000, 48:902-912.

105. Anderson LV, Harrison RM, Pogue R, Vafiadaki E, Pollitt C, Davison K, Moss JA, Keers S, Pyle A, Shaw PJ, Mahjneh I, Argov Z, Greenberg CR, 
Wrogemann K, Bertorini T, Goebel HH, Beckmann JS, Bashir R, Bushby KM: Secondary reduction in calpain 3 expression in patients with limb girdle muscular dystrophy type $2 \mathrm{~B}$ and Miyoshi myopathy (primary dysferlinopathies). Neuromuscul Disord 2000, 10:553-559.

106. Matsuda C, Hayashi YK, Ogawa M, Aoki M, Murayama K, Nishino I, Nonaka I, Arahata K, Brown RH Jr: The sarcolemmal proteins dysferlin and caveolin3 interact in skeletal muscle. Hum Mol Genet 2001, 10:1761-1766.

107. Lo HP, Cooper ST, Evesson FJ, Seto JT, Chiotis M, Tay V, Compton AG, Cairns AG, Corbett A, MacArthur DG, Yang N, Reardon K, North KN: Limbgirdle muscular dystrophy: diagnostic evaluation, frequency and clues to pathogenesis. Neuromuscul Disord 2008, 18:34-44.

108. Chrobakova T, Hermanova M, Kroupova I, Vondracek P, Marikova T, Mazanec R, Zamecnik J, Stanek J, Havlova M, Fajkusova L: Mutations in Czech LGMD2A patients revealed by analysis of calpain3 mRNA and their phenotypic outcome. Neuromuscul Disord 2004, 14:659-665.

109. Anderson LV, Davison K, Moss JA, Young C, Cullen MJ, Walsh J, Johnson MA, Bashir R, Britton S, Keers S, Argov Z, Mahjneh I, Fougerousse F, Beckmann JS, Bushby KM: Dysferlin is a plasma membrane protein and is expressed early in human development. Hum Mol Genet 1999, 8:855-861.

110. De Luna N, Freixas A, Gallano P, Caselles L, Rojas-García R, Paradas C, Nogales G, Dominguez-Perles R, Gonzalez-Quereda L, Vílchez JJ, Márquez C, Bautista J, Guerrero A, Salazar JA, Pou A, Illa I, Gallardo E: Dysferlin expression in monocytes: a source of mRNA for mutation analysis. Neuromuscul Disord 2007, 17:69-76.

111. Fanin M, Nascimbeni AC, Angelini C: Muscle protein analysis in the detection of heterozygotes for recessive limb girdle muscular dystrophy type 2B and 2E. Neuromuscul Disord 2006, 16:792-799.

112. Moreira ES, Wiltshire TJ, Faulkner G, Nilforoushan A, Vainzof M, Suzuki OT, Valle G, Reeves R, Zatz M, Passos-Bueno MR, Jenne DE: Limb-girdle muscular dystrophy type $2 \mathrm{G}$ is caused by mutations in the gene encoding the sarcomeric protein telethonin. Nat Genet 2000, 24:163-166.

113. Olive M, Shatunov A, Gonzalez L, Carmona O, Moreno D, Quereda LG, Martinez-Matos JA, Goldfarb LG, Ferrer I: Transcription-terminating mutation in telethonin causing autosomal recessive muscular dystrophy type 2G in a European patient. Neuromuscul Disord 2008, 18:929-933.

114. Vainzof M, Moreira ES, Suzuki OT, Faulkner G, Valle G, Beggs AH, Carpen O, Ribeiro AF, Zanoteli E, Gurgel-Gianneti J, Tsanaclis AM, Silva HC, PassosBueno MR, Zatz M: Telethonin protein expression in neuromuscular disorders. Biochim Biophys Acta 2002, 1588:33-40.

115. Bione S, Maestrini E, Rivella S, Mancini M, Regis S, Romeo G, Toniolo D: Identification of a novel X-linked gene responsible for Emery-Dreifuss muscular dystrophy. Nat Genet 1994, 8:323-327.

116. Yorifuji H, Tadano Y, Tsuchiya Y, Ogawa M, Goto K, Umetani A, Asaka Y, Arahata K: Emerin, deficiency of which causes Emery-Dreifuss muscular dystrophy, is localized at the inner nuclear membrane. Neurogenetics 1997, 1:135-140.

117. Yates JR, Bagshaw J, Aksmanovic VM, Coomber E, McMahon R, Whittaker JL, Morrison PJ, Kendrick-Jones J, Ellis JA: Genotype-phenotype analysis in Xlinked Emery-Dreifuss muscular dystrophy and identification of a missense mutation associated with a milder phenotype. Neuromuscul Disord 1999, 9:159-165.

118. Manilal S, Recan D, Sewry CA, Hoeltzenbein M, Llense S, Leturcq F, Deburgrave N, Barbot J, Man N, Muntoni F, Wehnert M, Kaplan J, Morris GE: Mutations in Emery-Dreifuss muscular dystrophy and their effects on emerin protein expression. Hum Mol Genet 1998, 7:855-864.

119. Manilal S, Sewry CA, Man N, Muntoni F, Morris GE: Diagnosis of X-linked Emery-Dreifuss muscular dystrophy by protein analysis of leucocytes and skin with monoclonal antibodies. Neuromuscul Disord 1997, 7:63-66.

120. Sabatelli P, Squarzoni S, Petrini S, Capanni C, Ognibene A, Cartegni L, Cobianchi F, Merlini L, Toniolo D, Maraldi NM: Oral exfoliative cytology for the non-invasive diagnosis in X-linked Emery-Dreifuss muscular dystrophy patients and carriers. Neuromuscul Disord 1998, 8:67-71.

121. Mora M, Cartegni L, Di Blasi C, Barresi R, Bione S, Raffaele di Barletta M, Morandi L, Merlini L, Nigro V, Politano L, Donati MA, Cornelio F, Cobianchi F, Toniolo D: X-linked Emery-Dreifuss muscular dystrophy can be diagnosed from skin biopsy or blood sample. Ann Neurol 1997, 42:249-253.

122. Worman HJ, Bonne G: "Laminopathies": a wide spectrum of human diseases. Exp Cell Res 2007, 313:2121-2133.

123. Raffaele Di Barletta M, Ricci E, Galluzzi G, Tonali P, Mora M, Morandi L, Romorini A, Voit T, Orstavik KH, Merlini L, Trevisan C, Biancalana V,
Housmanowa-Petrusewicz I, Bione S, Ricotti R, Schwartz K, Bonne G, Toniolo D: Different mutations in the LMNA gene cause autosomal dominant and autosomal recessive Emery-Dreifuss muscular dystrophy. Am J Hum Genet 2000, 66:1407-1412.

124. Zhang Q, Bethmann C, Worth NF, Davies JD, Wasner C, Feuer A, Ragnauth CD, Yi Q, Mellad JA, Warren DT, Wheeler MA, Ellis JA, Skepper JN, Vorgerd M, Schlotter-Weigel B, Weissberg PL, Roberts RG, Wehnert M, Shanahan CM: Nesprin-1 and -2 are involved in the pathogenesis of Emery Dreifuss muscular dystrophy and are critical for nuclear envelope integrity. Hum Mol Genet 2007, 16:2816-2833.

125. Gueneau L, Bertrand AT, Jais JP, Salih MA, Stojkovic T, Wehnert M, Hoeltzenbein M, Spuler S, Saitoh S, Verschueren A, Tranchant C, Beuvin M, Lacene E, Romero NB, Heath S, Zelenika D, Voit T, Eymard B, Ben Yaou R, Bonne G: Mutations of the FHL1 gene cause Emery-Dreifuss muscular dystrophy. Am J Hum Genet 2009, 85:338-353.

126. Camacho Vanegas $O$, Bertini E, Zhang RZ, Petrini S, Minosse C, Sabatelli $P$, Giusti B, Chu ML, Pepe G: Ullrich scleroatonic muscular dystrophy is caused by recessive mutations in collagen type VI. Proc Natl Acad Sci USA 2001, 98:7516-7521.

127. Demir E, Sabatelli P, Allamand V, Ferreiro A, Moghadaszadeh B, Makrelouf M, Topaloglu H, Echenne B, Merlini L, Guicheney P: Mutations in COL6A3 cause severe and mild phenotypes of Ullrich congenital muscular dystrophy. Am J Hum Genet 2002, 70:1446-1458.

128. Pan TC, Zhang RZ, Sudano DG, Marie SK, Bonnemann CG, Chu ML: New molecular mechanism for Ullrich congenital muscular dystrophy: a heterozygous in-frame deletion in the COL6A1 gene causes a severe phenotype. Am J Hum Genet 2003, 73:355-369.

129. Scacheri PC, Gillanders EM, Subramony SH, Vedanarayanan V, Crowe CA, Thakore N, Bingler M, Hoffman EP: Novel mutations in collagen VI genes: expansion of the Bethlem myopathy phenotype. Neurology 2002, 58:593-602.

130. Lampe AK, Bushby KM: Collagen VI related muscle disorders. J Med Genet 2005, 42:673-685.

131. Ishikawa H, Sugie K, Murayama K, Ito M, Minami N, Nishino I, Nonaka I: Ullrich disease: collagen $\mathrm{VI}$ deficiency: EM suggests a new basis for muscular weakness. Neurology 2002, 59:920-923.

132. Mercuri E, Yuva Y, Brown SC, Brockington M, Kinali M, Jungbluth $H$, Feng $L$, Sewry CA, Muntoni F: Collagen VI involvement in Ullrich syndrome: a clinical, genetic, and immunohistochemical study. Neurology 2002, 58:1354-1359.

133. Hicks D, Lampe AK, Barresi R, Charlton R, Fiorillo C, Bonnemann CG, Hudson J, Sutton R, Lochmüller H, Straub V, Bushby K: A refined diagnostic algorithm for Bethlem myopathy. Neurology 2008, 70:1192-1199.

134. Sabatelli P, Bonaldo P, Lattanzi G, Braghetta P, Bergamin N, Capanni C, Mattioli E, Columbaro M, Ognibene A, Pepe G, Bertini E, Merlini L, Maraldi NM, Squarzoni S: Collagen VI deficiency affects the organization of fibronectin in the extracellular matrix of cultured fibroblasts. Matrix Biol 2001, 20:475-486.

135. Fanin M, Nascimbeni AC, Aurino S, Tasca E, Pegoraro E, Nigro V, Angelini C: Frequency of LGMD gene mutations in Italian patients with distinct clinical phenotypes. Neurology 2009, 72:1432-1435.

136. Muntoni F: Is a muscle biopsy in Duchenne dystrophy really necessary? Neurology 2001, 57:574-575.

doi:10.1186/2044-5040-1-24

Cite this article as: Barresi: From proteins to genes: immunoanalysis in the diagnosis of muscular dystrophies. Skeletal Muscle 2011 1:24. 